\title{
Chemical composition, antimicrobial activity and antioxidant capacity of some medicinal and aromatic plant extracts
}

\author{
Sıdıka Ekren ${ }^{1}$, Oktay Yerlikaya ${ }^{2 \star}$, Hatice Eda Tokul ${ }^{1}$, Aslı Akpınar ${ }^{2}$ and Merve Açu ${ }^{2}$ \\ ${ }^{1}$ Department of Field Crops, Faculty of Agriculture, Ege University, 35100, Bornova-Izmir/Turkey. \\ ${ }^{2}$ Department of Dairy Technology, Faculty of Agriculture, Ege University, 35100, Bornova-Izmir/Turkey.
}

Accepted 20 November, 2012

\begin{abstract}
In this study, the chemical composition, antimicrobial activity and antioxidant capacity of essential oils obtained from oregano (Origanum onites L.), sage (Salvia triloba L.), mint (Mentha piperita L.), and laurel (Laurus nobilus L.) were determined. The essential oil components were identified by gas chromatography (GC) analysis. The antimicrobial activity of the oils was determined against some pathogenic and lactic acid bacteria using a disc diffusion method. The total antioxidant capacity was evaluated spectrophotometrically as $\alpha$-tocopherol equivalent. The GC analysis showed that the major constituents of the oils were monoterpene hydrocarbons and phenolic monoterpenes, but the concentration of these compounds varied greatly among the oils examined. The main components of the essential oil were carvacrol, menthol, 1-8 cineole, thujon, camphor and menthone. The results of the antimicrobial assay showed that majority of essential oils showed varied levels of antimicrobial activity against the tested indicator strains. Also, all essential oils exhibited antioxidant effect on oils used in the experiment. The results of this study confirmed the possibility of using some essential oils in food as preservation systems for growth of foodborne bacteria, improving antioxidant properties and extend the shelf-life of processed foods.
\end{abstract}

Key words: Essential oil, chemical composition, antimicrobial activity, antioxidant capacity, medicinal and aromatic plants.

\section{INTRODUCTION}

Since ancient times, the crude herbal extracts of aromatic plants have been in use for different purposes such as food, perfumery and drugs. The medicinal properties of these plants have been investigated in the recent scientific developments throughout the world, due to their potent antioxidant activity (Heath, 1981; Patel et al., 2010). Many medicinal plants contain large amount of antioxidants, such as polyphenols, vitamin C, vitamin E, selenium, B carotene, lycopene, lutein and other carotenoids which play important roles in adsorbing and neutralizing free radicals (Djeridane et al., 2006). Many studies have shown that phenolic compounds in

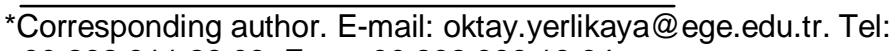
+9023231129 03. Fax: +902323881864. medicinal plant essential oils display antioxidant activity as a result of their capacity to scavenge free radicals (Seyoum et al., 2006; Ozkan et al., 2010). Also, the essential oils from medicinal plants have been confirmed to possess antioxidant activities (Baratta et al., 1998; Bozin et al., 2007; Tepe et al., 2004; Wei and Shibamoto, 2010; Politeo et al., 2007).

The use of essential oils for treatment of various inflammatory diseases like rheumatism, fever, diabetes suggest that oxidative stress play a role in human disease and intake of antioxidants may improve human health (Burits et al., 2001). Plant derived antioxidant components such as flavonoids and terpenoids are increasingly aimed as important dietary antioxidant factors (Haraguchi, 2001). There is a strong need for effective antioxidants from natural source as alternatives of commercial antioxidants. Research shows that the 
main compounds of the essential oils have antioxidant activity (Ruberto and Barata, 2000). Also, recent studies focused on antimicrobial properties of essential oils (Nakamura et al., 2004). Essential oils and/or their components are becoming increasingly popular as natural antimicrobial agents to be used for a wide variety of purposes, including food preservation, complementary medicine and natural therapeutics. At present essential oils are used by the flavouring industry for flavour enhancement and for their antioxidant effect, for the potential use of these oils as natural antimicrobial agent has been less explored (Di Pasqua et al., 2005).

Among the countries in the Middle East, the richest flora has been reported for the Anatolian peninsula. Turkish flora includes more than 9000 plants species. About 3000 are endemic and 1000 are used as medicine and aromatic in Turkey (Ozgüven et al., 2005). The main medicinal and aromatic plants are produced, exported and sold in the Akhtar or Attars such as laurel leaves, anise seed, thyme and oregano, cumin seeds, sage, fennel seeds, juniper, berries, red pepper, linden flowers, rosemary, mahaleb, sumac and mint, etc. The list of natural remedies was sold in Akhtar shops since ancient times in our country.

The antibacterial activities of spices and essential oils have been known for a long time, and a number of research projects on the antimicrobial effect of oregano, thyme and savory plants, essential oils and their derivatives have been reported. Research reports on the essential oil composition of black thyme ( $T$. spicata) and oregano (O. onites) are limited, whereas the oils of wild oregano (O. minutiflorum) and wild savory (S. cuneifolia) have never been studied before. Especially, wild oregano is endemic in Turkey, and so it has a special importance for the study (Baydar et al., 2004).

Aromatic and medicinal plants are the source of natural antioxidants thanks to their main secondary metabolites such as polyphenols and essential oils (Singer et al., 2003). Earlier authors (Tanaka et al., 1988) observed a direct correlation between antioxidant activity and reducing power of certain plant extracts.

The aim of the present study was to assess the composition, antimicrobial activity, and antioxidant capacity of four essential oils from medicinal and aromatic plants which are sold in Akhtar.

\section{MATERIALS AND METHODS}

The plant of sage (Salvia triloba L.), mint (Mentha piperita L.), laurel (bay) (Lauris nobilis L.), and oregano (Origanum onites L.) were purchased in Akhtar in Izmir, Turkey.

\section{Essential oil analysis (\%)}

Dry leaf materials of $10 \mathrm{~g}$ were subjected to a $3 \mathrm{~h}$ water-distillation using a Neo-Clevenger apparatus and the extracted essential oils were stored at $4^{\circ} \mathrm{C}$ until gas chromatography (GC) analysis.
Essential oil ratios of the plants were determined by volumetric method (ml/100 g) (Wichtl, 1971).

\section{Composition of the essential oils}

Essential oils were analyzed by GC. Gas chromatography analysis of the essential oils was performed using an Agilent $6890 \mathrm{~N}$ chromatograph equipped with flame-ionization detection (GC-FID). Compounds were separated on a $30 \mathrm{~m} \times 0.25 \mathrm{~mm}, 0.25 \mu \mathrm{m}$ film thickness, DB-Wax capillary column, with helium as carrier gas at a constant flow rate of $1 \mathrm{ml} / \mathrm{min}$. The oven temperature program was $45^{\circ} \mathrm{C}$ (2 $\left.\mathrm{min}\right), 45$ to $250^{\circ} \mathrm{C}\left(3^{\circ} / \mathrm{min}\right), 250^{\circ} \mathrm{C}$ (34 $\left.\mathrm{min}\right)$, and the injector and detector temperatures were $250^{\circ} \mathrm{C}$. Identification of the components was based on comparison of their relative retention times (RT) with those of authentic standards found in the laboratory.

\section{Antimicrobial activity}

In vitro antimicrobial activity of essential oils against Esherichia coli 0157:H7 ATCC 8739, Listeria monocytogenes ATCC 7644, Salmonella typhimurium ATCC 14028, Staphylococcus aureus ATCC 25923, Enterococcus faecalis ATCC 29212, Enterococcus faecium B-2354, Enterococcus casseliflavus B-3502, Streptococcus thermophilus ST36, Lactobacillus casei B-1922, Lactobacillus casei L26, Lactobacillus rhamnosus B-442, Lactobacillus rhamnosus CSL, Lactobacillus plantarum B-4496, and Lactobacillus plantarum CSL was determined by disc diffusion method. Suspensions of the test bacteria were added which contained $25 \mathrm{ml}$ sterile tryptic soy agar at 44 to $48^{\circ} \mathrm{C}$, and poured into Petri plates $(8 \mathrm{~cm}$ diameter). Essential oils were applied at doses of 0 (control), 5, 10, 15, $20 \mu \mathrm{l}$ (Bauer et al., 1966; Celikel and Kavas, 2008). Plates were incubated in appropriate temperature for $48 \mathrm{~h}$. After the incubation, forming inhibition zones were measured in the medium as millimeter $(\mathrm{mm})$. Antimicrobial activity was evaluated as negative (-) for zone diameters less than $6 \mathrm{~mm}$. The experiment was performed in duplicate.

\section{Antioxidant capacity}

The antioxidant activity of the extract was evaluated by the phosphomolybdenum method according to the procedure describe by Prieto et al. (1999). The assay was based on the reduction of Mo (VI) to Mo (V) by the extract and subsequent formation of a green phosphate/Mo (V) complex at acidic $\mathrm{pH}$. An aliquot $0.2 \mathrm{ml}$ of sample solution containing a reducing species was combined in tubes with $2 \mathrm{ml}$ of reagent solution $(0.6 \mathrm{M}$ sulfuric acid, $28 \mathrm{mM}$ sodium phosphate and $4 \mathrm{mM}$ ammonium molybdate). The tubes containing the reaction solution were incubated at $95^{\circ} \mathrm{C}$ for $90 \mathrm{~min}$. After the samples had cooled to room temperature, the absorbance of the solution of each was measured at $695 \mathrm{~nm}$ using a spectrophotometer (Analytikjena Spekol-1300) against blank after cooling to room temperature. Methanol $(0.2 \mathrm{ml})$ in the place of extract was used as the blank. The antioxidant capacities were expressed as equivalents of gram $\alpha$-tocopherol.

\section{RESULTS AND DISCUSSION}

\section{Chemical composition of the essential oils}

The chemical composition of the essential oils of oregano, sage, mint and laurel are shown in Table 1. 
Table 1. Chemical composition of essentials oil (\%).

\begin{tabular}{lcccc}
\hline Chemical component & $\begin{array}{c}\text { Oregano } \\
\text { (Origanum onites L.) }\end{array}$ & $\begin{array}{c}\text { Mint } \\
\text { (Mentha piperita L.) }\end{array}$ & $\begin{array}{c}\text { Sage } \\
\text { (Salvia triloba L.) }\end{array}$ & $\begin{array}{c}\text { Laurel } \\
\text { (Laurus nobilus L.) }\end{array}$ \\
\hline$\alpha$-Pinen & 0.14 & 0.37 & 3.91 & 5.77 \\
B-Pinen & 0.07 & 0.12 & 3.25 & 0.76 \\
Myrecene & 0.38 & 0.14 & 3.50 & - \\
$\alpha$-Humulene & - & 0.859 & 1.30 & 0.12 \\
trans-caryophylene & - & 1.71 & 5.22 & 3.06 \\
$\gamma$-Terpinen & 1.70 & 0.11 & 1.17 & 0.15 \\
Menthofuran & 0.11 & 6.13 & - & - \\
Carvon & 0.37 & 10.61 & - & 0.42 \\
Pulegon & 0.30 & 2.12 & - & - \\
Menthone & 0.13 & 20.15 & - & - \\
Thujon & 1.05 & - & 30.55 & - \\
Borneol & 1.59 & 0.06 & 5.01 & - \\
Carvacrol & 65.49 & - & 2.44 & 0.25 \\
1-8-cineole & - & 5.59 & 11.45 & 44.97 \\
Menthol & 0.07 & 35.12 & - & - \\
Linalool & 12.54 & - & - & 9.22 \\
Camphor & 1.00 & 1.50 & 20.33 & 1.20 \\
Thymol & 2.75 & - & 1.11 & 0.15 \\
\hline
\end{tabular}

The essential oil from oregano consisted mainly of carvacrol $(65.49 \%)$, linalool (12.54\%), thujon (11.05\%), $\gamma$ terpinene $(1.70 \%)$ and borneol $(1.59 \%)$ respectively. Many studies reported that main components of essential oil from oregano are carvacrol, thujon, $\gamma$ terpinene, $\rho$ cymene, borneol, linalool and $\alpha$ terpinene (Baser et al., 1993; Ceylan et al., 2003; Demirci et al., 2004; Toncer et al., 2009; Basmacıoğlu-Malayoğlu et al., 2011; Ozkan and Erdogan, 2011).

In mint essential oil, 13 compounds were identified (Table 1). The main components were menthol, menthone, menthofuran, 1-8 cineole, pulegan, trans coryophyllene. Several studies reported that the essential oilcomponent of mint are menthol, menthone, carvone, menthofuran, 1-8 cineole (Ozgüven and Kırıcı, 1999; Kızıl et al., 2010; Telci and Sahbaz, 2005; Mkaddem et al., 2009; Agarwal, 2008; Telci et al., 2011).

The thujon (30.55\%), camphor (20.33\%), 1-8 cineole $(11.45 \%)$, trans coryophyllene $(5.22 \%)$ and borneol $(5.01 \%)$ constituted the main fraction of sage. Similar results have been published for other studies (Delamare et al., 2007; Marino et al., 2001; Putievsky et al., 1990).

The most abundent components in laurel essential oil were 1-8 cineole $(44.97 \%)$, linalool $(9.22 \%)$, a pinen $(5.77 \%)$, camphor $(1.20 \%)$, and trans coryophyllene $(3.06 \%)$. Similar results were obtained by other researsces (Basmacıoğlu-Malayoğlu, 2011; Politeo et al., 2007; Kosar et al., 2005; Sangun et al., 2007).

\section{Antimicrobial activity}

Antimicrobial activity of essential oils and inhibition zones are given Table 2. Majority of the essential oils showed varied levels of antimicrobial activity against the tested strains and the diameters of growth inhibition zone ranged from $7 \mathrm{~mm}$ to $22 \mathrm{~mm}$ for test bacteria (including the diameter of the disc- $6 \mathrm{~mm}$ ). The results of antimicrobial assay showed that the most effective essential oil was extracted from Origanum onites $L$. then followed by Laurus nobilus L., Mentha piperita L. and Salvia triloba L., respectively.

The highest antimicrobial activity was determined in Laurus nobilus $\mathrm{L}$. then followed by Origanum onites $\mathrm{L}$., Mentha piperita L. and Salvia triloba L., respectively. 20 $\mu \mathrm{l}$ application of oil extraction in all examples showed inhibition effect against $E$. coli and S. typhimurium. When application of at least $15 \mu \mathrm{l}$ Origanum onites L. had an effect on S. thermophilus ST36, it was seen that only extraction of Origanum onites $L$. oil had an effect on $L$. rhamnosus CSL. As well, it was seen that amount of oil had a positive effect on inhibition levels; Origanum onites L. oil can be a good source of antimicrobial agents in some food products for bio preservation and medical applications.

Askun et al. (2009) investigated the antimicrobial activity of Origanum onites L. against to Staph. aureus, E. faecalis, B. cereus, E. coli, and S. typhimurium and the best antibacterial activity (MIC $640 \mu \mathrm{g} / \mathrm{mL}$ ) was shown against $S$. typhimurium.

Lisin et al. (1999) researched the antimicrobial activity of essential oils that were extracted from two oregano species. The results show that while it was effective on $S$. aureus and $E$. coli, there was no effect on $P$. aeruginosa. In another study, essential oils of laurel and two oregano 
Table 2. Antimicrobial activity of essential oils extracted from various plants (mm).

\begin{tabular}{|c|c|c|c|c|c|c|c|c|c|c|c|c|c|c|c|c|}
\hline Indicator strain & $\begin{array}{c}S \\
(5 \mu \mathrm{L})\end{array}$ & $\begin{array}{c}\text { S } \\
(10 \mu \mathrm{L})\end{array}$ & $\begin{array}{c}S \\
(15 \mu \mathrm{L})\end{array}$ & $\begin{array}{c}S \\
(20 \mu L)\end{array}$ & $\begin{array}{c}\text { M } \\
(5 \mu \mathrm{L})\end{array}$ & $\begin{array}{c}M \\
(10 \mu L)\end{array}$ & $\begin{array}{c}M \\
(15 \mu \mathrm{L})\end{array}$ & $\begin{array}{c}M \\
(20 \mu \mathrm{L})\end{array}$ & $\begin{array}{c}\mathrm{L} \\
(5 \mu \mathrm{L})\end{array}$ & $\begin{array}{c}\mathrm{L} \\
(10 \mu \mathrm{L})\end{array}$ & $\begin{array}{c}\mathrm{L} \\
(15 \mu \mathrm{L})\end{array}$ & $\begin{array}{c}\mathrm{L} \\
(20 \mu \mathrm{L})\end{array}$ & $\begin{array}{c}0 \\
(5 \mu \mathrm{L})\end{array}$ & $\begin{array}{c}0 \\
(10 \mu \mathrm{L})\end{array}$ & $\begin{array}{c}0 \\
(15 \mu \mathrm{L})\end{array}$ & $\begin{array}{c}0 \\
(20 \mu \mathrm{L})\end{array}$ \\
\hline Listeria monocytogenes ATCC 7644 & - & - & - & 7 & - & - & - & - & - & - & 8 & 9 & - & 8 & 8 & 9 \\
\hline Escherichia coli 0157:H7 ATCC 8739 & 9 & 12 & 13 & 15 & - & 12 & 12 & 14 & 14 & 18 & 18 & 19 & - & 9 & 10 & 10 \\
\hline Salmonella typhimurium ATCC 14028 & 9 & 10 & 11 & 12 & 16 & 18 & 19 & 20 & 8 & 10 & 11 & 12 & 20 & 21 & 22 & 23 \\
\hline Staphylococcus aureus ATCC 25923 & - & - & 7 & 7 & - & - & - & - & - & 9 & 10 & 10 & 10 & 12 & 12 & 13 \\
\hline Enterococcus faecalis ATCC 29212 & - & - & - & - & - & - & - & 7 & - & - & 8 & 8 & - & - & 8 & 8 \\
\hline Enterococcus faecium B-2354 & - & - & - & - & - & - & - & 8 & - & - & - & 8 & - & 8 & 8 & 9 \\
\hline Enterococcus casseliflavus B- 3502 & - & - & - & - & - & - & - & - & - & - & 8 & 8 & - & 7 & 9 & 12 \\
\hline Streptococcus thermophilus ST36 & - & - & - & - & - & - & - & - & - & - & - & - & - & - & 8 & 10 \\
\hline Lactobacillus casei B-1922 & - & - & - & - & - & - & - & - & - & - & - & - & 7 & 8 & 10 & 12 \\
\hline Lactobacillus casei B26 & - & - & - & - & - & - & - & - & - & - & - & - & 9 & 13 & 10 & 11 \\
\hline Lactobacillus rhamnosus B-442 & - & - & 7 & 8 & - & - & - & - & - & - & - & 7 & 7 & 8 & 8 & 11 \\
\hline Lactobacillus rhamnosus CSL & - & - & - & - & - & - & - & - & - & - & - & - & 7 & 7 & 9 & 10 \\
\hline Lactobacillus plantarumB-4496 & - & - & - & - & - & - & - & 8 & - & - & - & - & 13 & 14 & 14 & 16 \\
\hline Lactobacillus plantarum CSL & - & - & - & - & - & - & 7 & 7 & - & - & - & - & 7 & 8 & 11 & 13 \\
\hline
\end{tabular}

S, sage (Salvia triloba L.); M, mint (Mentha piperita L.); L, laurel (Laurus nobilus L.); O, oregano (Origanum onites L.).

species were tried on E. coli. It was seen that two oregano species had the highest bacteriostatic and bactericidal effect (Burt and Reinders, 2003).

Ertürk et al. (2010) examined the antimicrobial activity of oregano and mint volatile oils on 21 bacteria and 7 yeasts by disc diffusion method. Researchers showed that oregano volatile oil was more effective than mint oil; also the difference between the oregano and mint inhibition field diameters was significant.

In a research, Nalbantbaşı and Gölcü (2009) indicated that oregano and mint had an antimicrobial effect on E. gallinarum, E. faecalis, $B$. subtilis, E. coli, Candida albicans, Saccharomyces cerevisiae and Candida crusei. In a study by Aydın (2008) did in Kafkas University, it was seen that while oregano had a strong antimicrobial effect on $E$. coli 0157: $H 7, S$. aureus, Yersinia enterocolitica and Listeria monocytogenes, mint was effective on $S$. aureus,
$Y$. enterocolitica and L. monocytogenes. Our results are in concert with the results of various researches (Dorman et al., 2000; O'Gara et al., 2000; Burt et al., 2003; Benli and Yigit, 2005).

\section{Antioxidant capacity}

Antioxidant research is an important topic in the medical field as well as in the food industry. Recent researches with important bioactive compounds in many plant and food materials have received much attention. Total antioxidant capacity of Salvia officinalis, Menta longifolia, Laurus nobilis and Thymus vulgaris extracts, expressed as the number of gram equivalents of a-tocopherol, is shown in Table 3.

All essential oils exhibited antioxidant effect on oils used in the experiment. The highest antioxidant activity was found in Laurus nobilus L. then followed by Origanum onites L., Mentha piperita L. and Salvia triloba L., respectively.

Saha et al. (2008) showed the antioxidant potential of the methanol extract of the leaves of Mimusops elengi Linn. by using 1, 1-diphenyl-2picrylhydrazyl (DPPH) scavenging assay, reducing power and total antioxidant capacity. They found that total antioxidant activity was also found to increase in a dose dependent manner. Bozan et al. (2002) worked on antioxidant properties of several Salvia species, and found that $S$. fruticosa had moderate antioxidant activity in comparison to the other species. The antioxidant activity of the samples was found to be higher for the second harvesting year whereas there were no significant differences between wild and cultivated $S$. fruticosa during storage period (Dincer et al., 2012).

In another study, the essential oil of aerial parts of Salvia lanigera Poir. (Lamiaceae) growing wild 
Table 3. Antioxidant capacity of medicinal and aromatic plant extracts ( $\mathrm{nmol} \alpha$-tocopherol/g).

\begin{tabular}{lc}
\hline Plant extract & Total antioxidant capacity \\
\hline (Salvia triloba L.) sage & 1.156 \\
(Mentha longifolia L.) mint & 2.023 \\
(Laurus nobilis L.) laurel & 5.431 \\
(Origanum onites L.) oregano & 3.200 \\
\hline
\end{tabular}

in Cyprus was obtained by hydro-distillation and was analysed by GC and GC-MS. A total of 67 compounds, representing $93.6 \%$ of the oil, were identified. Antioxidant activity of the oil was evaluated by using DPPH and FRAPS methods together with three antioxidant standards, L-ascorbic acid, tert-butyl-4-hydroxy toluene $(\mathrm{BHT})$ and gallic acid. A nearly identical trend was observed in FRAP assay and the comparable results (5.56 \pm 0.2 and $6.44 \pm 0.4 \mathrm{mmol}$ Trolox/L for DPPH and FRAP, respectively) reflect either comparable amounts of radical scavengers and reductants in the sample or the possibility that oil components are similarly reactive against both oxidant systems (Tenore et al., 2011).

Hinneburg et al. (2006) showed that $1 \mathrm{~g}$ of laurel extract was as effective as about $212 \mathrm{mg}$ of trolox in the prevention of lipid peroxidation. In the linoleic acid peroxidation assay, $1 \mathrm{~g}$ of the laurel extract was as effective as $212 \mathrm{mg}$ of trolox. Thus, it is a promising alternative to synthetic substances as food ingredients with antioxidant activity.

Inan et al. (2012) determined antioxidant effects of mint (Mentha spicata L.), laurel (Laurus nobilis L.) and myrtle leaf (Myrtus communis L.) essential oils on pomegranate kernel, poppy, grape and linseed. Essential oils at the level of 0.01 and $0.05 \%$ were added into the oils and stored in a drying oven $\left(60^{\circ} \mathrm{C}\right)$ for six weeks and analyzed for peroxide value. An important increase was observed in the peroxide values during the experiment period. The levels of $0.05 \%$ of essential oils were found to save the values lower than levels of $0.01 \%$ and control samples. In conclusion, the use of essential oils improved the oxidative stability and fastened the viscosity values of the edible oils.

\section{Conclusions}

The results reveal that the main component of the essential oil of carvacrol (65.49\%), linalool (12.54\%), thujon (11.05\%) in oregano; menthol $(35.12 \%)$, menthone $(20.15 \%)$, carvon $(10.61 \%)$ in mint; thujon $(30.55 \%)$, camphor $(20.33 \%), 1-8$ cineole $(11.45 \%)$ in sage; and 1 8 cineole $(44.97 \%)$, linalool $(9.22 \%)$, $\alpha$ pinen $(5.77 \%)$ in laurel. The results of antimicrobial assay show that the most effective essential oil was extracted from Origanum onites L. followed by Laurus nobilus L., Mentha piperita L. and Salvia triloba L., respectively. The highest antioxidant activity was found in Laurus nobilus L. then followed by Origanum onites L., Mentha piperita L. and Salvia triloba L., respectively.

\section{ACKNOWLEDGEMENT}

A part of this research was presented at the "FoodMicro Congrees 2012-Global Issues in Food Microbiology, 3-7 September 2012, Istanbul-Turkey" as poster proceeding.

\section{REFERENCES}

Agarwal AA (2008). Chemical composition of major essential oil of India. Published by Swaraj Herbal Plants Ltd. Barabanki, India. p. 281.

Askun T, Tumen G, Satil F, Ates M (2009). Characterization of the phenolic composition and antimicrobial activities of Turkish medicinal plants. Pharm. Biol. 47:563-571.

Aydin BD (2008). Bazı Tıbbi Bitki ve Baharatların Gıda Patojenleri Üzerine Antibakteriyel Etkisinin Araştırılması. Kafkas Üniv. Vet. Fak. Derg. 14:83-87.

Baratta MT, Dorman HJD, Deans SG, Biondi DM, Ruberto G (1998). Chemical composition, antimicrobial and antioxidative activity of laurel, sage, rosemary, oregano and coriander essential oils. J. Essent. Oil Res. 10(6):618-627.

Baser KHC, Özek T, Tümen G, Sezik E (1993). Composition of the essential oils of Turkish Origanum species with commercial importance. J. Essent. Oil Res. 5(6):619-623.

Basmacıoğlu-Malayoğlu H, Özdemir P, Hameş-Kocabaş EE (2011). Chemical composition and antibacterial activity of the essential oils from some plant species. Ege Üniv. Ziraat Fak. Derg. 48:11-18. ISSN 1018-8851.

Bauer AW, Kirby WMM, Sherries JC, Turck M (1966). Antibiotic susceptibility testing by single disk method. Am. J. Clin. Pathol. 45:493-496.

Baydar H, Sagdic O, Ozkan G, Karadogan T (2004). Antibacterial activity and composition of essential oils from Origanum, Thymbra and Satureja species with commercial Importance in Turkey. Food control 15(3):169-172.

Benli M, Yigit N (2005). Ülkemizde Yaygın Kullanımı Olan Kekik (Thymus vulgaris) Bitkisinin Antimikrobiyal Aktivitesi. Orlab On-Line Mikrobiyoloji Dergisi 3(8):1-8.

Bozan B, Ozturk N, Kosar M, Tunalier Z, Baser KHC (2002). Antioxidant and free radical scavenging activities of eight Salvia species. Chem. Nat. compound 38:198-200.

Bozin B, Mimica-Dukic N, Samojlik I, Jovin E (2007). Antimicrobial and antioxidant properties of rosemary and sage (Rosmarinus officinalis $L$. and Salvia officinalis L., Lamiaceae) essential oils. J. Agric. Food Chem. 55:7879-7885.

Burits M, Asres K, Bucar F (2001). The antioxidant activity of the essential oils of Artemisia afra, A. abyssinica and Juniperus procera. Phytother. Res. 15:103-108.

Burt SA, Reinders RD (2003). Antibacterial activity of selected plant essential oils against Escherichia coli O157:H7. Lett. Appl. Microbiol. 36:162-167. 
Celikel N, Kavas G (2008). Antimicrobial properties of some essential oils against some pathogenic microorganisms. Czech J. Food Sci. 26:174-181.

Ceylan A, Bayram E, Sahbaz N, Otan H, Karaman S (2003). Yield performance and essential oil composition of individual plants and improved clones of Origanum onites L. grown in the Aegean region of Turkey. Israel J. Plant Sci. 51(4):285-290.

Delamare AP, Moschen-Pistorello IT, Artico L, Atti-Serafani L, Echeverrigaray S (2007). Antibacterial activity of essential oils Salvia officinalis L. and Salvia triloba L. cultivated in South Brazil. Food Chem. 100:603-608.

Demirci F, Paper DH, Franz G, and Başer KHC (2004). Investigation of the Origanum onites L. Essential oil using the chorioallantoic membrane (CAM) Assay. J. Agric. Food Chem. 52(2):251-254.

Di Pasqua R, De Feo V, Villani F, Mauriello G (2005). In vitro antimicrobial activity of essential oils from mediterranean Apiaceae, Verbenaceae and Lamiaceae against foodborne pathogens and spoilage bacteria. Ann. Microbiol. 55:139-143.

Dincer C, Topuz A, Sahin-Nadeem H, Ozdemir KS, Cam IB, Tontul I, Gokturk RS, Ay ST (2012). A comparative study on phenolic composition, antioxidant activity and essential oil content of wild and cultivated sage (Salvia fruticosa Miller) as influenced by storage. Ind. Crops Prod. 39(2012):170-176.

Djeridane A, Yousfi M, Nadjemi B, Boutassouna D, Stocker P, Vidal N (2006). Antioxidant activity of some Algerian medicinal plants extract containing phenolic compounds. Food Chem. 97:654-660.

Dorman HJ, Deans SG (2000). Antimicrobial agents from plants: Antibacterial activity of plant volatile oils. J. Appl. Microbiol. 88:308316.

Ertürk R, Çelik C, Kaygusuz R, Aydın H (2010). Antimicrobial activities of commercial essential oils of thyme and mint. Cumhuriyet Med. J. $32: 281-286$

Haraguchi H (2001). Antioxidative plants constituents. In: Tringali C. (ed) bioactive compounds from natural sources. Taylor and Francis, London pp. 337-378.

Heath HB (1981). Source Book of Flavours. Westport: Avi. p. 890

Hinneburg I, Damien Dorman HJ, Hiltunen R (2006). Antioxidant activities of extracts from selected culinary herbs and spices. Food Chem. 97:122-129.

Inan Ö, Özcan MM, Juhaimi FYA (2012). Antioxidant effect of mint, laurel and myrtle leaves essential oils on pomegranate kernel, poppy, grape and linseed oils. J. Clean. Prod. 27(2012):151-154.

Kızıl S, Haşimi M, Tolan V, Kılınç E, Yüksel U (2010). Mıneral content, essential oil components and biological activity of two Mentha species (M. piperita L., M. spicata L.). Turk. J. Field Crops 15(2):148153

Kosar M, Tunalier Z, Ozek T, Kürkcüoglu M, Baser KHC (2005). Z. Naturforsch. C 60. pp. 501-504.

Lisin G, Safiyev S, Craker LE (1999). Antimicrobial activity of some essential oils. Acta Hortic. (ISHS) 501:283-288.

Marino M, Bersani C, Comi G (2001). Impedance measurements to study the antimicrobial activity of essential oils from Lamiaceae and Compositae. Int. J. Food Microbiol. 67:187-195.

Mkaddem M, Bouajıla J, Ennajar M, Lebrihi A (2009). Chemical composition and antimicrobial and antioxidant activities of Mentha (longifolia L. and viridis) essential oils. J. Food Sci. 74:358-363.

Nakamura CV, Ishida K, Faccin LC, Filho BPD, Cortez DAG, Rozental S, De Souza W, Ueda-Nakamura T (2004). In vitro activity of essential oil from Ocimum gratissimum L. against four Candida species. Res. Microbiol. 155:579-586.

Nalbantbaşı Z, Gölcü A (2009). Kahramanmaraş Yöresine Ait Şifalı Bitkilerin Antimikrobiyal Aktiviteleri. KSÜ Doğa Bil. Derg. 12:1-8.

O'Gara E, Hill DJ, Maslin DJ (2000). Activities of garlic oil, garlic powder, and their diallyl constituents against Helicobacter pylori. Appl. Environ. Microbiol. 66:2269-2273.

Ozgüven M, Kırıcı S (1999). Research on yield essential oil contents and components of Minth (Mentha) Species in different ecologies. Turk. J. Agric. For. 23:465-472.

Ozgüven M, Sekin S, Gürbüz B, Şekeroğlu N, Ayanoğlu F, Ekren S (2005). Tütün, Tıbbi ve Aromatik Bitkiler Üretimi ve Ticareti. Türkiye Ziraat Mühendisliği VI. Teknik Kongresi. 3-7 Ocak 2005. Ankara.
Ozkan A, Erdogan A, Sokmen M (2010). Antitumoral and antioxidant effect of essential oils and in vitro antioxidant properties of essentia oils and aqueous extracts from Salvia pisidica. Biologia 65:990-996.

Ozkan A, Erdogan A (2011). A comparative evaluation of antioxidant and anticancer activity of essential oil from Origanum onites L. (Lamiaceae) and its two major phenolic components. Turk J. Biol. 35:735-742.

Patel RV, Patel PR, Kajal SS (2010). Antioxidant activity of some selected medicinal plants in Western Region of India. Adv. Biol. Res. $4(1): 23-26$

Politeo O, Jukic M, Milos M (2007). Chemical composition and antioxidant activities of free volatile aglycones from laurel (Lauris nobilis L.) compared to its essential oil. Croatica Chemica Acta. CCACAA 80(1):121-126.

Prieto P, Pineda M, Aguilar M (1999). Spectrophotometric quantitation of antioxidant capacity through the formation of a phosphomolybdenum complex: specific application to the determination of Vitamin E. Anal. Biochem. 269:337-341.

Putievsky E, Ravid D, Diwan-Rinzler N, Zohary D (1990). Genetic affinities and essential oil composition of Salvia officinalis L. Salvia fruticosa Mill. and their hybrids. Flavour Fragr. J. 5:121-123.

Ruberto G, Baratta MT (2000). Antioxidant activity of selected essential oil components in two lipid model systems. Food Chem. 69:167-174.

Saha MR, Hasan SMR, Akter R, Hossain MM, Alam MS, Alam MA, Mazumder MEH (2008). In vitro free radical scavenging activity of methanol extract of the leaves of Mimusops elengi Lınn. Bangl. J. Vet. Med. 6(2):197-202.

Sangun MK, Aydın E, Timur M, Karadeniz H, Çalışkan M, Özkan A (2007). Comparison of chemical composition of the essential oil of Laurus nobilis L. leaves and fruits from different regions of Hatay, Turkey. J. Environ. Biol. 28(4):731-733.

Seyoum A, Asres K, El-Fiky FK (2006). Structure-radical scavenging activity relationship of flavonoids. Phytochemistry 67:2058-2070.

Singer AC, Crowley D, Thompson IP (2003). Secondary plant metabolites in phytoremediation and biotransformation. Trends Biotechnol. 21:123-130.

Tanaka M, Kuie CW, Nagashima Y, Taguchi T (1988). Applications of antioxidative maillard reaction products from histidine and glucose to sardine products. Nippon Suisan Gakkaishi 54:1409-1414.

Telci I, Sahbaz N (2005). Determination of agronomic and essential oil properties of peppermint (Mentha piperita L.) in various ages of plantation. J. Agron. 4:103-108.

Telci I, Kacar O, Bayram E, Arabacı O, Demirtas I, Yılmaz G, Ozcan I, Sonmez C, Goksu E (2011). The effect of ecological conditions on yield and quality traits of selected peppermint (Mentha piperita L.) clones. Ind. crops prod. 34(1):1193-1197.

Tenore GC, Ciampagli AR, Arnold NS, Piozzi F, Napolitano F, Rigano $D$, Senatore $F$ (2011). Antimicrobial and antioxidant properties of the essential oil of Salvia lanigera from Cyprus. Food Chem. Toxicol. 49:238-243.

Tepe B, Dönmez E, Unlu M, Candan F, Daferera D, Vardar-Unlu G, Polissiou M, Sokmen A (2004). Antimicrobial and antioxidative activities of the essential oils and methanol extracts of Salvia cryptantha (Montbret et Aucher ex. Benth.) and Salvia multicaulis (vahl). Food Chem. 84:519-525.

Toncer Ö, Karaman S, Kızıl S, Diraz E (2009). Changes in essential oil composition of oregano (Origanum onites L.) Due to diurnal variations at different development stages. Not. Bot. Hortic. Agrobot. Cluj 37(2):177-181.

Wei A, Shibamoto T (2010). Antioxidant/lipoxgenase inhibitory activities and chemical compositions of selected essential oils. J. Agric. Food Chem. 58(12):7218-7225.

Wichtl M (1971). Die Pharmakognostichchemische Analys. Band 12 Frankfurt/M. 